\title{
ゲノム解析から見た大腸菌ゲノムの可塑性
}

\author{
林 哲也* \\ 宮崎大学フロンティア科学実験総合センター生命科学研究部門生命環境科学分野 \\ T 889-1692 宮崎県宮崎郡清武町大字木原 5200
}

\section{Genome plasticity of Escherichia coli; insights from genome analysis}

Tetsuya Hayashi

Division of Bioenvironmental Science, Frontier Science Research Center, University of Miyazaki

5200, Kihara, Kiyotake, Miyazaki 889-1692, Japan

\section{1. 細菌ゲノム解析の進展}

1995 年にインフルエンザ菌の全ゲノム配列が決定さ れて以来, 各種細菌のゲノム解析が急速に進んだ。特に この数年の進展は著しく, 既に 150 以上の細菌のゲノム 配列が決定され，さらに 300 以上の細菌でゲノム解析が 進行中である。こういったゲノム解析の進展によって, 各菌の生物学的特性の概要が明らかになるとともに，ゲ ノム情報基盤が確立されたことによって, 研究の手法自 体も大きく変化しつつある．アレイを用いたゲノムワイ ドな発現解析や遺伝子レパートリー解析などがその典型 例である．細菌ゲノム解析の成果として，もう一つ強調 すべき点は，それが生物学全般に対しても大きなインパ クトを与えていることである。特に，生物進化という観 点からは, 細菌の進化と多様化の機構がかなり明確にな ってきている。

ここでは，ゲノム解析からみえてきた細菌ゲノムの可 塑性と多様化の実例として, 我々が進めている0157を 中心とした病原性大腸菌ゲノム研究の結果を紹介する.

\section{2. 大腸菌の多様性とゲノム解析}

大腸菌が遺伝的多様性に富んだ集団であることはよく 知られているが，基本的には非病原性で，種々の動物の

\footnotetext{
*E-mail: thayash@med.miyazaki-u.ac.jp

受付: 2005 年 4 月 4 日 受理: 2005 年 4 月 4 日

(C) 日本環境変異原学会
}

腸管常在菌である。しかし, 病原性大腸菌と呼ばれる一 部の菌株はヒトに対して病原性を示す。病原性大腸菌は 腸管感染症を起こすものと腸管外感染症を引き起こすも のに分けられるが，前者はさらに，症状・細胞付着様 式・毒素産生などによって, 腸管出血性大腸菌 (enterohemorrhagic E. coli: EHEC) など，6種類以上のタイプに 分類され, それぞれ異なったタイプの腸管感染症を引き 起こす. 後者にも尿路病原性大腸菌など, 様々な夕イプ の病原型を示す菌株が存在する。このうち, 非病原性大 腸菌 K-12 株, 腸管出血性大腸菌 O157 堺株, 尿路病原性大 腸菌 CFT073 株の全ゲノム配列が既に決定されている。

\section{K-12と0157のゲノム比較からみえる 大腸菌ゲノムの可塑性と多様化のメカニズム}

K-12 はDNA組換え実験などに汎用されている実験室 株であり，病原性はない。一方，O157 は EHECに属す る下痢原性大腸菌の一つである。 EHEC は脳症・HUS といった重症合併症を引き起こすことや，しばしば大規 模な集団感染を引き起こすために，最も問題となってい る病原性大腸菌である. EHEC の中にも様々な血清型を 持つ菌株が存在するが, 一番問題となっているのは O157の血清型を持つ菌株であり, 我々が全配列を決定 した O157堺株は, 1996 年に大阪・堺市で発生した大集 団感染の原因菌である。

両株のゲノムを較べた時, 最も顕著な違いは染色体サ イズの違いであり，0157の染色体が5.5 Mbであるのに 
対して, K-12は $4.6 \mathrm{Mb}$ である. しかし， $4.1 \mathrm{Mb}$ にたた る染色体領域は共通であり, 塩基レベルで $98.3 \%$ 同一 性を示す，重要な点は，両株が異なった大腸菌系統に属 することであり, 両者に共通な $4.1 \mathrm{Mb}$ は大腸菌染色体の 基本骨格であって，そこにコードされる約 3,700 個の遺 伝子の大部分は大腸菌の基本的遺伝子七ットとみなして も良い。一方，菌株特異的配列は，この基本骨格に大小

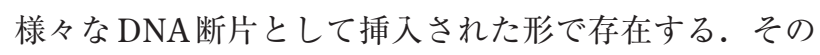
全長は O157では $1.4 \mathrm{Mb}, \mathrm{K}-12$ でも $0.5 \mathrm{Mb}$ であり, そ の多くが大腸菌以外の菌種に由来する外来性 DNA であ る.さらに，どちらにおいても，大きな菌株特異的領域 の多くがプロファージもしくはプロファージ様配列であ り，特に0157では 24 種類のプロファージ・プロファー ジ様配列が同定され，O157 特異配列の 3 分の 2 をこれら の因子が占める。また, 0157 特異的領域には志賀毒素
遺伝子など多数の病原性関連遺伝子が存在する.

以上の知見は, 大腸菌のゲノムは従来考えられていた 以上に可塑性が高く, 非常に多様性に富んだものである ことを示している. 同時に，このような遺伝的多様性は 無規則に出現したものではなく, 約 $4.1 \mathrm{Mb}$ の基本骨格 上にどのような外来性遺伝子を獲得したかによって規定 されており，その獲得にはバクテリオファージが重要な 役割を果たしたことが示唆される。

本講演では，このような K-12 と 0157 のゲノム比較の 結果とそれに基づいて推定される大腸菌の多様化機構に 加えて, 0157 に扮ける外来性遺伝子の大腸菌固有の遺 伝子制御系への統合様式，さらには，0157株間でのゲ ノム多様性に関しても, 最新の知見を紹介した。 